\title{
Nine cycles of mass selection for increasing oil content in two maize (Zea mays L.) synthetics
}

\author{
Milorad Rosulj, S. Trifunovic and I. Husic \\ Breeding Department, Maize Research Institute, Zemun Polje, Belgrade, Yugoslavia.
}

\begin{abstract}
The objectives of this study were to estimate changes in oil content, grain yield, percentage of broken plants and changes in yield components in the maize populations DS7u and YuSSSu. As estimations were performed at $\mathrm{C} 0$ and C9 for both populations, it was possible to observe changes occurring following long-term mass selection for high oil content. The synthetic population DS7u population was developed by recombination of 29 inbred lines of Yugoslav, Canadian and US origin. The synthetic population YuSSSu population is an lowa Stiff Stalk Synthetic - BSS(R)C5. Progenies were derived according to the North Carolina Design II. Results indicated that nine cycles of selection led to statistically significant increase in oil content and statistically significant decrease for grain yield in both populations. Estimates of additive and dominance variances for grain oil content were highly significant in $\mathrm{C} 0$ and $\mathrm{C} 9$ of the population DS7u population. Dominance variance showed significance in the initial cycle of the population YuSSSu population, but it was not detected in the course of nine cycles of mass selection. Additive and dominance variances for grain yield were highly significant in both initial populations. Loss of significance did not result from selection, while the proportion of dominance vs. additive variance became greater. High narrow-sense heritability was detected for grain yield, oil content, moisture content, and cob percent in the initial cycles of both populations. Mass selection resulted in increased heritability for oil content and cob percent in the DS7u population and increased heritability for percentage of broken plants in the YuSSSu population. The strongest additive correlation between oil content and other traits was detected for grain moisture $\left(r_{a}=0.90^{*}\right)$ in the C9 of the DS7u population.
\end{abstract}

Key words: corn, mass selection, high oil populations, components of genetic variance, additive and phenotypic correlations.

Received: June 13, 2002; accepted: October 18, 2002.

\section{Introduction}

Recurrent selection is a cyclic breeding procedure designed to improve trait means of populations under selection. This can be accomplished by a gradual increase in the frequency of favourable alleles with the simultaneous maintenance of genetic variability. Mass selection is the oldest and simplest form of recurrent selection. Its simplicity and the completion of a cycle in the course of one year are its greatest advantages over other methods. Moreover, mass selection is most efficient for traits with high heritability. Hopkins initiated studies on methods for increasing maize grain oil content at the University of Illinois in 1896. The studies established over a century ago are still in progress. Dudley and Lambert (1992) published results from 90 generations of selection for increased and decreased oil and protein content in maize. Summarized results of the same studies were also previously published

Send correspondence to M. Rosulj. Maize Research Institute "Zemun Polje", S. Bajica 1, 11185 Zemun Polje, Yugoslavia. Phone: +381 113756 704, fax: +381 113754 707. E-mail: mrosulj@yahoo.com. previously, but they referred to shorter periods of selection (Smith, 1908; Woodwort et al., 1952; Dudley, 1973; Dudley et al., 1974; Dudley, 1977). Dudley and Lambert (1992) reported that the reached grain oil content in the Illinois High Oil population was $22 \%$, but the upper plateau from selection had not been achieved yet.

Using this method, with slight modifications, Alexander (1962) increased oil content in BSSS from 4.2\% to 7\%. After 62 cycles of mass selection oil content in the open-pollinated variety "Burr White" increased from 4.7\% to over $15 \%$ (Alexander, 1977). After the $76^{\text {th }}$ cycle, the increase amounted to $19 \%$, i.e., to $279 \%$ of the original population mean (Dudley, 1977).

Grain oil content increased from $5.1 \%$ to $17 \%$ in the population Alexho synthetic population after 24 cycles of phenotypic recurrent selection for high oil content. The total increase was $231 \%$ of the original population mean. The average change in oil percent oil was $4.9 \%, 2.1 \%$ and $2.4 \%$ cycle $^{-1}$ per se, cycles crossed to B73, and cycles crossed to R802A, respectively (Misevic et al., 1989). According to Saratlic (1994) oil content increased by $120 \%$ and $97 \%$ 
after seven cycles of mass selection in the DS7u and YuSSSu populations, respectively.

Sprague and Brimhall (1950) and Sprague et al. (1952) used a variation of mass selection. Oil content was increased from $4.97 \%$ to $7 \%$ or $0.41 \%$ cycle $^{-1}$ during five seasons of selection.

Recently mass selection has gained even greater importance, due to the introduction of the TOP CROSS system into production for oil content. The TOP CROSS system licensed by DuPont may minimize the yield disadvantage associated with conventional high oil corn hybrids (Edge, 1997; Lambert et al., 1997). The TOP CROSS system uses the sterile version of a hybrid (90-95\%) as a means to obtain high yield, and high-oil population $(5-10 \%)$ as a pollinator. Due to the effect of xenia half of the oil content of the oil population is transferred to the sterile (female) version of the hybrid. In this way it is possible to gain both high yield and high oil content.

The objectives of this study were to estimate the following in the DS7u and YuSSSu maize populations: (i) mean, (ii) additive and dominance variance as well as their interaction with the environment, (iii) heritability, and (iv) phenotypic and additive genetic correlations. Because estimations were performed at $\mathrm{C} 0$ and $\mathrm{C} 9$ for both populations, it was possible to observe total realized changes occurring during the long-term mass selection for high oil content.

\section{Material and Methods}

\section{Populations and genetic materials}

According to Dumanovic (1995), the DS7u synthetic population DS7u was developed by inter-mating 29 inbred lines of Yugoslav, Canadian, and U.S. origin. During the first two years, inter-mating was performed in an isolated field with moderate selection for plant type and resistance to lodging. The YuSSSu synthetic population YuSSSu is from the Iowa Stiff Stalk Synthetic, BSS(R)C5. Selection for high oil content was initiated in 1981 in both populations. The number of individual kernels analyzed within one ear, as well as the number of selected kernels from one ear, varied over cycles. Furthermore, selection intensity also varied from 15 to $25 \%$.

The genetic material evaluated in the present study was derived from $\mathrm{DS} 7 \mathrm{uC} 0, \mathrm{DS} 7 \mathrm{uC} 9, \mathrm{YuSSSuC0}$ and YuSSSuC9. One hundred and fifty plants per population were self-pollinated in 1996. Plants for pollination were randomly selected. Starting in the 1997 breeding nursery, a North Carolina Design II (factorial) mating design (Comstock and Robinson, 1948) was developed within each of the four populations. A series of half- and full-sib progenies was developed within each population by crossing four males ( $\mathrm{S} 0$ plants) with each of four females (S1 progenies). Each male was crossed with several plants within each S1 progeny and the resulting seed was bulked to obtain a representative sample of the gametic array of the original S0 female plants (Hallauer and Miranda Filho, 1988). The average number, variance and range of S1 plants sampled per female within each population were $12.3,8.2$, and 5-20 for DS7uC0; 11.4, 5.2, and 5-17 for DS7uC9; 11.0, 11.1, and 5-20 for YuSSSuC0; and 9.4, 13.5, and 6-19 for YuSSSuC9, respectively. Thus, each set of $4 \times 4$ matings produced progenies from a sampling of eight random plants within each population. To achieve a reasonable sample of individuals, a series of 14 sets of $4 \times 4$ matings was constructed within each population, yielding a total sampling of 112 random S0 plants from each population. Therefore, a total of 224 full-sib and half-sib progenies (14 sets of 16 progenies) from each population was developed for field evaluation.

\section{Experimental field design and traits studied}

The total of 896 entries (full- and half-sib progenies) was evaluated within 14 sets of a replication-within-sets randomized incomplete block experiment (Comstock and Robinson, 1948). Each set consisted of 16 full- and half-sib progenies from each of the four individual populations completely randomized within each of two replications. The entries were grown at Zemun Polje, Indjija, and Becej, Yugoslavia, in 1998 and Zemun Polje, Indjija, and Srbobran, Yugoslavia, in 1999. A plot consisted of $9.20 \mathrm{~m}$ long hand-planted rows with $0.70 \mathrm{~m}$ between rows. Over-planted plots were thinned to a uniform plant density of approximately 62.111 plants ha $^{-1}$. All experiments were machine-cultivated and manually weeded as necessary for proper weed control.

Harvest was done by hand. Data were observed for grain yield ( $\mathrm{mg} \mathrm{ha}^{-1}$, adjusted to $14.0 \%$ grain moisture), grain moisture (\%) at harvest, root lodging (percentage of plants leaning more than $30^{\circ}$ from the vertical) and stalk lodging (percentage of plants broken at/or below the primary ear node), and cob percent (\%). A separate trial, with slightly lower plant density (59.523 plants ha $\left.{ }^{-1}\right)$ was set up in order to determine oil content (\%). A plot consisted of $9.20 \mathrm{~m}$ long hand-planted rows with $0.70 \mathrm{~m}$ between rows. Due to the effect of xenia, oil content was determined under conditions of controlled pollination. Five plants per replication in each progeny row were selfed. The same number of kernels was selected from each ear and used to form the group sample. From group sample The three primary samples of the total weight of $60 \mathrm{~g}$ were selected from the group sample. These primary samples were used to determine oil content by the non-destructive method of Nuclear Magnetic Resonant (NMR) spectroscopy.

\section{Statistical methods}

The analysis of all trait data was based on plot means. Data for each trait were analyzed by pooling over sets and combining across environments. All effects in the model were considered random. 
Full- and half-sib family means were used to construct the distribution histogram for each population. Kolmogorov-Smirnov's one-sample test and the Shapiro-Wilk and Lilliefors statistic tests were applied to test distribution (Snedecor and Cochran, 1989). Values that are significant indicate non-normality in the distribution. Estimates of skewness and kurtosis were calculated for each population distribution (Snedecor and Cochran, 1989). In the case of the sample from a normal distribution, the coefficients of skewness and kurtosis are distributed approximately around mean zero with a standard deviation of $(6 / \mathrm{n})^{1 / 2}$ and $(24 / n)^{1 / 2}$, respectively. Positive values of coefficients of skewness indicate an elongated upper tail, while negative value point to an elongated lower tail. Furthermore, positive coefficients of kurtosis suggest a distribution with tails longer than a normal one with equal standard deviation, whereas negative estimates of the coefficients indicate a distribution with a flat-topped characteristic.

The analyses of individual populations pooled over sets and combined across environments were calculated to partition the within population variation for each population into male, female and male $\mathrm{x}$ female interaction sources of variation. Because the genetic expectations for mean squares for male and female sources of variation were the same, their degrees of freedom and sums of squares were pooled to give more precise estimates of the variation among half-sib families. The within population $\mathrm{x}$ environment interaction degrees of freedom and sums of squares were partitioned similarly. The within population error mean squares were used to test significance of the within population $\mathrm{x}$ environment interaction sources of variation. The appropriate interaction mean square terms were then used for testing the within population components. Since direct tests of male, female, and pooled components were not available, (Satterthwaite, 1946) approximation was used to construct the appropriate $F$-test.

For the case of a Design II analysis with $\mathrm{F}=0$, covariances of full- (FS) and half-sibs (HS) are obtained by expanding the following general representation using $\mathrm{F}=0$ (Comstock and Robinson, 1948):

$$
\operatorname{Cov} .(F S)_{i j}=\sum\left[\frac{1+F}{2}\right]^{i+2 j} \sigma_{i j}^{2}
$$

and

$$
\operatorname{Cov} .(H S)=\sum\left[\frac{1+F}{4}\right]^{i} \sigma_{i 0}^{2}
$$

where " $\mathrm{i}$ " represents Additive and " $\mathrm{j}$ " represents Dominance. Then for Design II

$$
\operatorname{Cov} .(F S)=\frac{\sigma_{A}^{2}}{2}+\frac{\sigma_{D}^{2}}{4}
$$

and
$\operatorname{Cov} .(H S)=\frac{\sigma_{A}^{2}}{4}$

Then, the expected values for covariances of relatives are:

$$
\operatorname{Cov} .(F S)=\sigma_{M_{0}}^{2}+\sigma_{F_{0}}^{2}+\sigma_{M_{0} x F_{0}}^{2}
$$

and

$$
\operatorname{Cov} .(H S)=\sigma_{M_{0}}^{2}=\sigma_{F_{0}}^{2} .
$$

Solving for expected mean square terms from the combined analysis of variance and equating to genetic parameters results in the following equations for estimating the genetic components of variance where $\sigma_{M_{0}}^{2}=\sigma_{F_{0}}^{2}$, and represents variation among males and females at $\mathrm{F}=0$ (combined in this analysis), and $\sigma_{M_{0} x F_{0}}^{2}$ represents variation among male by female crosses at $\mathrm{F}=0$.

$$
\begin{gathered}
\sigma_{F_{0}}^{2}=\operatorname{Cov} \cdot(H S)_{0}=\frac{\sigma_{A}^{2}}{4} \\
\sigma_{M_{0}}^{2}=\operatorname{Cov} \cdot(H S)_{0}=\frac{\sigma_{A}^{2}}{4}
\end{gathered}
$$

and

$$
\sigma_{M_{0} \times F_{0}}^{2}=\operatorname{Cov} \cdot(F S)_{0}-2 \operatorname{Cov} \cdot(H S)_{0}=\frac{\sigma_{D}^{2}}{4}
$$

Additive genetic variance $\left(\sigma_{A}^{2}\right)$, dominance genetic variance $\left(\sigma_{D}^{2}\right)$, additive genetic variance $\mathrm{x}$ environment $\left(\sigma_{A E}^{2}\right)$, dominance genetic variance $\mathrm{x}$ environment $\left(\sigma_{D E}^{2}\right)$, and error variance $\left(\sigma_{e}^{2}\right)$ were calculated by equating the observed mean squares to the expected mean squares and solving the resulting system of equations.

Heritability was estimated on a half-sib progeny mean basis for individual traits within each population. Variance component and heritability estimates were declared significant if their values were two times greater than their standard errors (Falconer, 1989). Phenotypic and additive genetic correlations among traits within populations were calculated from the appropriate covariance components (Mode and Robinson, 1959).

\section{Results}

\section{Population means}

Oil content in the $\mathrm{DS} 7 \mathrm{uC} 0$ population was $4.46 \%$ with an average coefficient of variance (CV) of $12.1 \%$. Grain yield averaged $8.95 \mathrm{mg} \mathrm{ha}^{-1}$ and ranged from $6.52 \mathrm{mg} \mathrm{ha}^{-1}$ at Zemun Polje in 1999 to $11.07 \mathrm{mg} \mathrm{ha}^{-1}$ in Becej in 1998. The CV for grain yield was $13.5 \%$. The average value for moisture content was $24.2 \%$. Mean values for the percentage of lodged and broken plants and cob percent were $4.7 \%$ and $17.5 \%$, respectively, with corresponding CV of $144.5 \%$ and $3.5 \%$ (Table I). 
Table I - Means, error variances $\left(\sigma_{\mathrm{e}}^{2}\right)$, coefficients of variation (CV \%) from the combined analyses of variance across six environments, KomogorovSmirnov (K-S), Shapiro-Wilk (W), Lilliefors (L) test, coefficients of Skewness (Sk) and Kurtosis (Ku) of five traits measured in the DS7uC0, DS7uC9, YuSSSuC0 and YuSSSuC9 populations.

\begin{tabular}{|c|c|c|c|c|c|c|c|c|}
\hline Trait* & Mean $\pm \mathrm{SE}$ & $\sigma_{\mathrm{e}}^{2}$ & CV $(\%)$ & $\mathrm{K}-\mathrm{S}$ & W & $\mathrm{L}$ & Sk & $\mathrm{Ku}$ \\
\hline \multicolumn{9}{|c|}{ Oil content $(\%)$} \\
\hline $\mathrm{DS} 7 \mathrm{uC} 0$ & $4.46 \pm 0.02$ & 0.15 & 12.10 & 0.03 & $0.98 * *$ & $*$ & $-0.40^{* *}$ & $1.07 * *$ \\
\hline DS7uC9 & $10.91 \pm 0.03$ & 0.67 & 9.35 & $0.06 * *$ & $0.97 * *$ & ** & $0.78 * *$ & $2.12 * *$ \\
\hline YuSSSuC0 & $4.17 \pm 0.02$ & 0.16 & 14.86 & 0.03 & $0.98 * *$ & $*$ & $0.66^{* *}$ & $2.32 * *$ \\
\hline YuSSSuC9 & $8.99 \pm 0.03$ & 0.71 & 9.37 & $0.07 * *$ & $0.87 * *$ & ** & $-2.12 * *$ & $12.42 * *$ \\
\hline \multicolumn{9}{|c|}{ Grain yield $\left(\mathrm{mg} \mathrm{ha}^{-1}\right)$} \\
\hline $\mathrm{DS} 7 \mathrm{uC} 0$ & $8.95 \pm 3.24$ & 1.45 & 13.47 & 0.04 & 0.98 & ns & 0.25 & 0.40 \\
\hline DS7uC9 & $7.81 \pm 2.69$ & 1.02 & 12.95 & 0.07 & $0.94 * *$ & $* *$ & $0.57 * *$ & -0.30 \\
\hline YuSSSuC0 & $7.44 \pm 2.66$ & 1.03 & 16.05 & 0.06 & $0.97 *$ & $*$ & 0.03 & -0.45 \\
\hline YuSSSuC9 & $6.61 \pm 3.35$ & 1.40 & 17.89 & $0.09 *$ & $0.89 * *$ & ** & $1.60^{* *}$ & $4.47 * *$ \\
\hline \multicolumn{9}{|c|}{ Grains moisture $\left(\mathrm{g} \mathrm{kg}^{-1}\right)$} \\
\hline $\mathrm{DS} 7 \mathrm{uC} 0$ & $242 \pm 4.57$ & 0.12 & 15.26 & $0.04 * *$ & $0.98 * *$ & $* *$ & $0.20 * *$ & $0.99 * *$ \\
\hline DS7uC9 & $277 \pm 5.32$ & 0.17 & 7.27 & $0.05^{* *}$ & $0.96 * *$ & ** & -0.05 & $1.13^{* *}$ \\
\hline YuSSSuC0 & $306 \pm 3.88$ & 0.18 & 10.94 & $0.09 * *$ & $0.95 * *$ & $* *$ & $0.67 * *$ & -0.01 \\
\hline YuSSSuC9 & $307 \pm 4.09$ & 0.11 & 6.95 & $0.06^{* *}$ & $0.96 * *$ & $* *$ & $0.38 * *$ & 0.09 \\
\hline \multicolumn{9}{|c|}{ Cob proportion (\%) } \\
\hline $\mathrm{DS} 7 \mathrm{uC0}$ & $17.5 \pm 5.72$ & 0.05 & 3.49 & $0.05^{* *}$ & $0.99 * *$ & ** & $0.55^{* *}$ & $5.16^{* *}$ \\
\hline DS7uC9 & $20.1 \pm 7.57$ & 0.07 & 8.94 & $0.07 * *$ & $0.98 * *$ & ** & $-0.73 * *$ & $3.95^{* *}$ \\
\hline YuSSSuC0 & $22.9 \pm 5.31$ & 0.08 & 9.93 & $0.05^{* *}$ & $0.94 * *$ & $* *$ & $0.33 * *$ & $1.47 * *$ \\
\hline YuSSSuC9 & $21.4 \pm 6.72$ & 0.14 & 7.03 & $0.07 * *$ & $0.95 * *$ & ** & $4.32 * *$ & $65.55^{* *}$ \\
\hline \multicolumn{9}{|c|}{ Root and stalk lodging (\%) } \\
\hline $\mathrm{DS} 7 \mathrm{uC0}$ & $4.7 \pm 14.94$ & 26.10 & 144.49 & $0.33 * *$ & $0.93 * *$ & $* *$ & $2.55^{* *}$ & $9.00 * *$ \\
\hline DS7uC9 & $13.7 \pm 23.90$ & 92.76 & 81.18 & $0.19^{* *}$ & $0.96 * *$ & $* *$ & $1.42 * *$ & $1.87^{* *}$ \\
\hline YuSSSuC0 & $10.6 \pm 20.64$ & 61.92 & 89.89 & $0.25^{* *}$ & $0.94 * *$ & $* *$ & $2.27 * *$ & $5.81 * *$ \\
\hline YuSSSuC9 & $7.9 \pm 20.37$ & 64.46 & 109.59 & $0.26^{* *}$ & $0.90 * *$ & $* *$ & $2.28^{* *}$ & $6.35^{* *}$ \\
\hline
\end{tabular}

*Grain yield, grain moisture, cob proportion and root and stalk lodging were measured in six environments, whereas oil content was measured in two environments.

***Significant at the 0.05 and 0.01 probability level, respectively, ns represents non-significant.

The grain oil content mean in the $\mathrm{DS} 7 \mathrm{uC} 9$ population was $10.91 \%$ with an average $\mathrm{CV}$ of $9.4 \%$. Grain yield averaged $7.81 \mathrm{mg} \mathrm{ha}^{-1}$ and ranged from $5.63 \mathrm{mg} \mathrm{ha}^{-1}$ in Indjija in 1999 to $10.45 \mathrm{mg} \mathrm{ha}^{-1}$ in Becej in 1998. The CV for grain yield was $13 \%$. The average value of moisture content value was $27.7 \%$. Mean values of the percentage of lodged and broken plants and cob percent were $13.7 \%$ and $20.1 \%$, respectively, with corresponding $\mathrm{CV}$ of $81.2 \%$ and $8.9 \%$ (Table I).

The grain oil content mean in the YuSSSuC0 population was $4.17 \%$ with an average CV of $14.9 \%$. Grain yield averaged $7.44 \mathrm{mg} \mathrm{ha}^{-1}$ and ranged from $4.40 \mathrm{mg} \mathrm{ha}^{-1}$ at Zemun Polje in 1999 to $11.07 \mathrm{mg} \mathrm{ha}^{-1}$ in Becej in 1998. The $\mathrm{CV}$ for grain yield was $16.1 \%$. The average value of moisture content value was $30.6 \%$. Mean values of the percentage of lodged and broken plants and cob percent were $10.7 \%$ and $22.9 \%$, respectively, with corresponding CV of $89.9 \%$ and $9.9 \%$ (Table I).
The grain oil content mean in the YuSSSuC9 population was $8.99 \%$ with an average $\mathrm{CV}$ of $9.4 \%$. Grain yield averaged $6.61 \mathrm{mg} \mathrm{ha}^{-1}$ and ranged from $4.56 \mathrm{mg} \mathrm{ha}^{-1}$ at Zemun Polje in 1999 to $9.23 \mathrm{mg} \mathrm{ha}^{-1}$ in Becej in 1998. The $\mathrm{CV}$ for grain yield was $17.9 \%$. The average value of moisture content was $30.7 \%$. Mean values of the percentage of lodged and broken plants and cob percent were $7.8 \%$ and $21.4 \%$, respectively, with corresponding CV of $109.6 \%$ and $7 \%$ (Table I).

\section{Among populations analysis and means}

Nine cycles of mass selection resulted in highly significant increases in oil content in both investigated populations. This increase amounted to $16.1 \%$ and $12.8 \%$ cycle $^{-1}$ based on $\mathrm{C} 0$ in the DS7 $u$ and YuSSSu populations, respectively. mean comparisons between the initial and the final cycle of phenotypic recurrent selection for high oil content showed a highly significant grain yield reduction in both 
populations. This reduction amounted to $1.41 \% \mathrm{cycle}^{-1}$ and $1.24 \%$ cycle $^{-1}$ based on C0 in the DS7u and YuSSSu populations, respectively. Grain moisture content was very significantly increased in the DS7u population $(24.2 \%$ vs. $27.7 \%$ ), while there was no statistically significant change in the YuSSSu population $(30.6 \%$ vs. $30.7 \%)$. This increase, converted to relative parameters, amounted to $1.57 \%$ cycle $^{-1}$ and $0.04 \%$ cycle $^{-1}$ in the DS7u and YuSSSu populations, respectively. Percentage of lodged and broken plants in the DS7u population significantly increased significantly $\left(21.16 \%\right.$ cycle $\left.^{-1}\right)$, while it significantly decreased significantly $\left(-2.92 \%\right.$ cycle $\left.^{-1}\right)$ in the YuSSSu population (Table I).

\section{Population distributions and tests of normality}

Normal distribution testing according to Kolmogorov-Smirnov's one-sample test showed that the frequency distribution for oil content in the $\mathrm{DS} 7 \mathrm{uC} 0$ population did not depart from normality. frequency distribution for oil content in the $\mathrm{DS} 7 \mathrm{uC} 9$ population significantly departed from normal distribution, which was confirmed by estimated values of all five parameters.

The Lilliefors and Shapiro-Wilk tests, as well as coefficients of kurtosis and skewness, indicated departure from normal distribution in the initial cycle of the YuSSSu population. Only the Kolmogorov-Smirnov one-sample test,

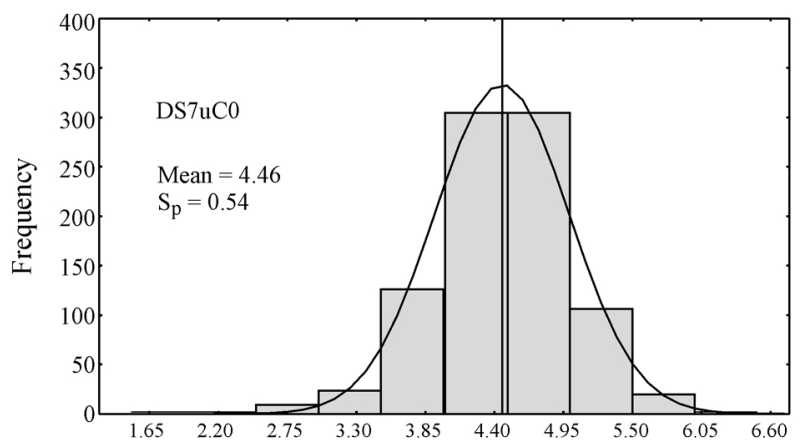

Oil content $(\%)$

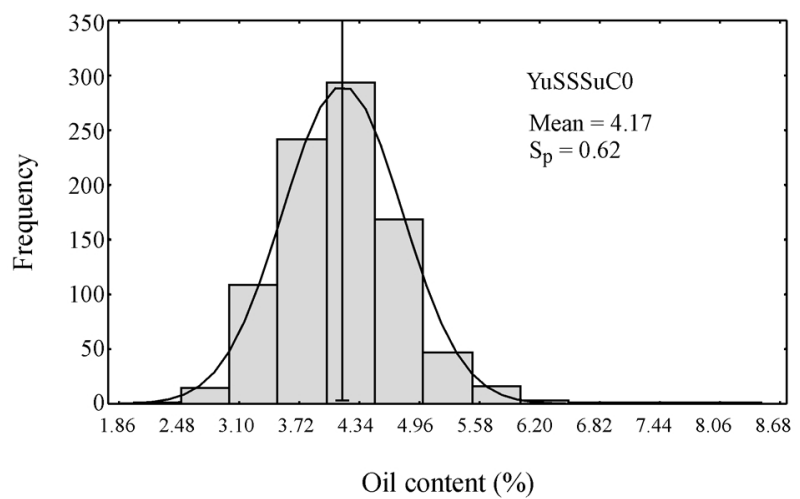

which is the least sensitive, was not statistically significant. Highly significant estimates of all five parameters in the YuSSSuC9 population pointed out that variability was greatly decreased (Table I, Figure 1).

Normal distribution testing according to the Kolmogorov-Smirnov one-sample test and the Shapiro-Wilk and Lilliefors tests showed that the frequency distribution for grain yield in the $\mathrm{DS} 7 \mathrm{uC} 0$ population did not depart from normality. Moreover, the coefficients of kurtosis and skewness were not statistically significant, indicating the fact that there was an adequate variability in the initial population. The Kolmogorov-Smirnov one-sample test and coefficients of kurtosis were not significant in the C9 of the same population, while the Shapiro-Wilk and Lilliefors tests and coefficient of skewness were highly significant, indicating that some unfavourable changes in grain yield in relation to the parameter of normal distribution occurred during nine cycles of mass selection for high oil.

frequency distribution for grain yield in the YuSSSuC0 population was normal according to the Kolmogorov-Smirnov one-sample test. However, the Lilliefors and Shapiro-Wilk tests were significant. Coefficients of kurtosis and skewness were not significant. Highly significant estimates of all five parameters in the YuSSSuC9 population point to the fact that frequency distribution for grain yield departed from normality (Table I, Figure 2).

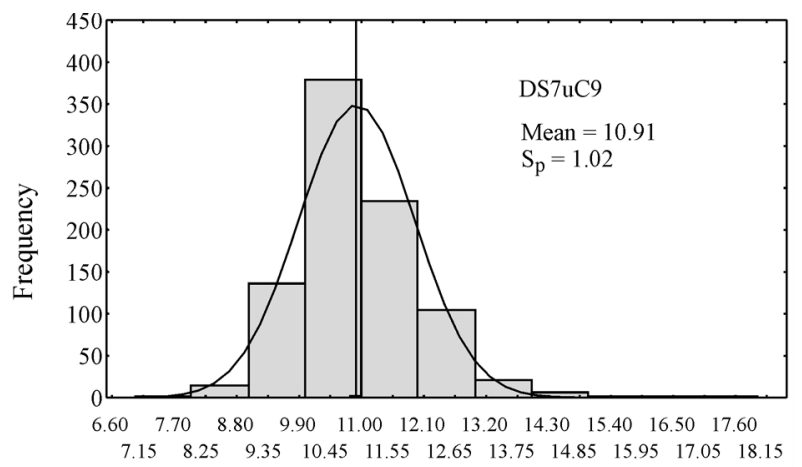

Oil content $(\%)$

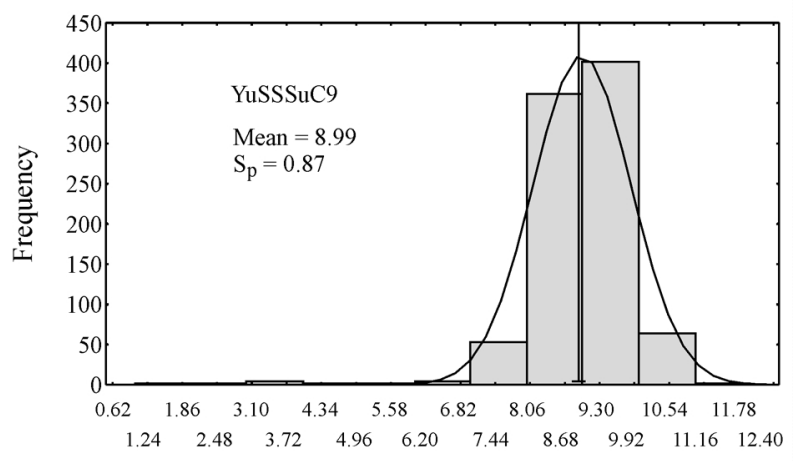

Oil content $(\%)$

Figure 1 - Frequency distribution, mean, and phenotypic standard deviation $\left(\mathrm{S}_{\mathrm{p}}\right)$ for oil content of full-sib and half-sib progenies from the DS7uC0, DS7uC9, YuSSSuC0, and YuSSSuC9 maize populations. Distances between class intervals are one half of a phenotypic standard deviation from the $\mathrm{DS} 7 \mathrm{uC} 0$ and $\mathrm{YuSSSuC0}$ populations. Vertical lines represent the population means. 

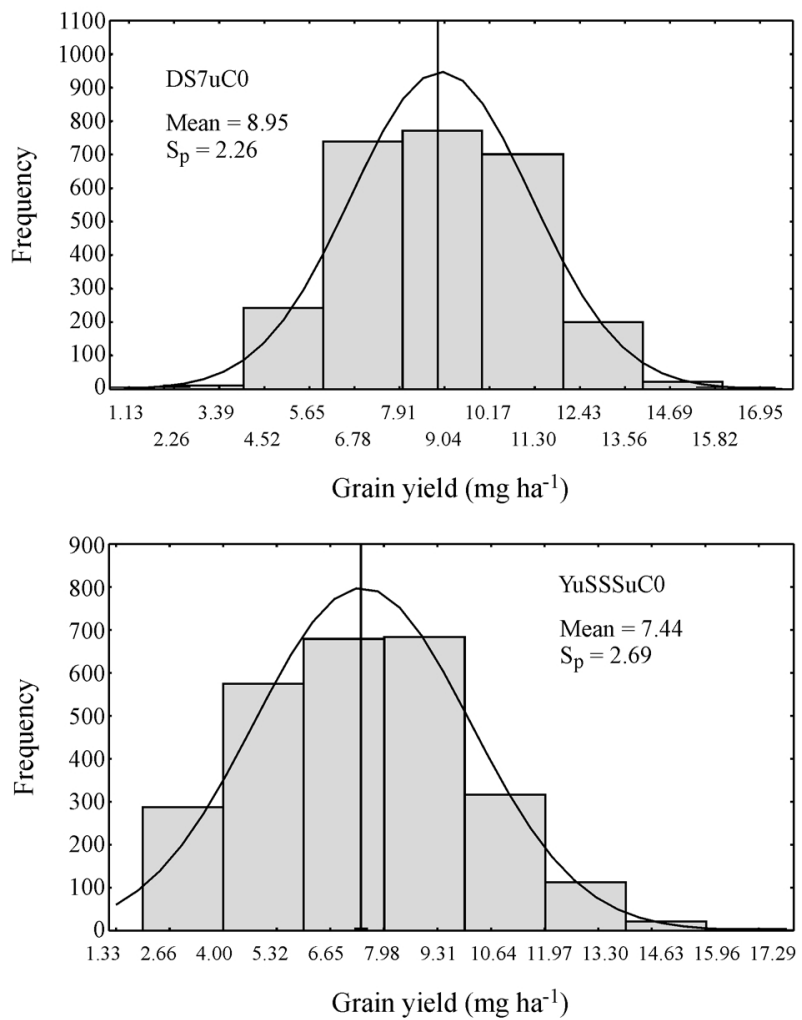
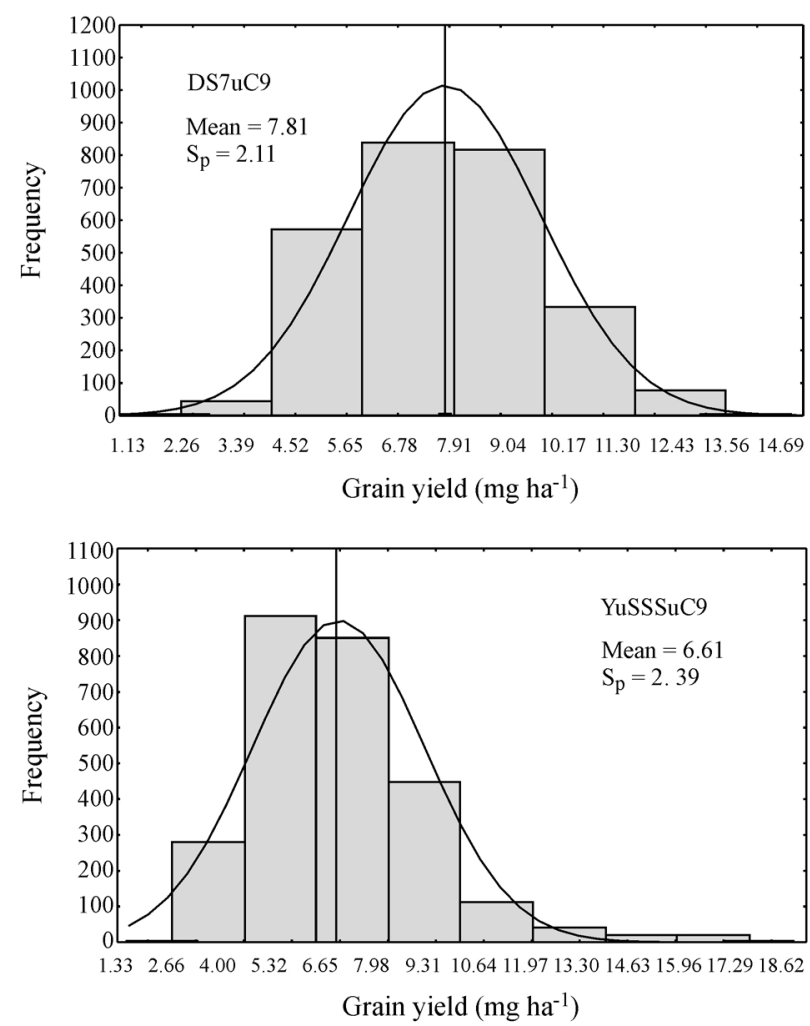

Figure 2 - Frequency distribution, mean, and phenotypic standard deviation $\left(\mathrm{S}_{\mathrm{p}}\right)$ for grain yield of full-sib and half-sib progenies from the DS7uC0, DS7uC9, YuSSSuC0, and YuSSSuC9 maize populations. Distances between class intervals are one half of a phenotypic standard deviation from the $\mathrm{DS} 7 \mathrm{uC0}$ and $\mathrm{YuSSSuC0}$ population. Vertical lines represent the population means.

\section{Genetic components of variance}

Estimates of genetic components of variance for grain oil content showed highly significant additive and dominance variance in the DS7uC0 population. The ratio of additive to dominance variance was 1:0.41. In the DS7uC9 population estimates of additive and dominance variance were also highly significant and the ratio increased to 1:0.23 in favour of additive variance. This ratio in the YuSSSuC0 population was also in favour of additive (1:0.61), but significance was shown only for dominance variance. Mass selection for high oil content led to the loss of additive and dominance variance significance in the $\mathrm{C} 9$ cycle of this population, although the additive:dominance variance ratio did not change (1:0.60). The interactions of additive and dominance variance with environments were not statistically significant for the four investigated populations (Table II).

On the other hand, for grain yield, the genetic components of variance and their interactions with environments were all highly significant. The greatest contribution of additive variance was detected in the $\mathrm{DS} 7 \mathrm{uC} 0$ population (1:0.20). Although the contribution of dominance variance increased after nine cycles of recurrent selection (1:0.30), additive variance was even greater. In the YuSSSu population the proportion of dominance variance was greater after selection (1:1.15) (Table II).
Additive variance and the dominance $\mathrm{x}$ environment interaction variance for grain moisture content were highly significant in all four populations. Changes occurring in the DS7 $u$ population included loss of significant dominance variance and the gain of significant additive $\mathrm{x}$ environment interaction variance. The additive:dominance variance ratio changed little. Additive variance had the greatest contribution in all four populations (Table II).

Considering the percentage of lodged and broken plants, high significance was determined for dominance $\mathrm{x}$ environment interaction in the population $\mathrm{DS} 7 \mathrm{uC} 0$ population, dominance and additive $\mathrm{x}$ environment interaction in the population DS7 $\mathrm{uC} 9$ population and additive $\mathrm{x}$ environment interaction in the population YuSSSuC0 population. Changes that occurred in the population DS7u population between the initial and final cycle referred to the gain in high significance of dominance variance and additive $\mathrm{x}$ environment interaction and the loss of significance in dominance $\mathrm{x}$ environment interaction. The additive:dominance variance ratio changed in favour of dominance. In the population YuSSSu population, additive $\mathrm{x}$ environment interaction lost its significance with the increased proportion of additive variance (Table II).

Additive variance and dominance $\mathrm{x}$ environments interaction was highly significant for cob percent in all four populations. Moreover, dominance variance was highly significant in the population YuSSSu population (Table II). 
Table II - Estimates of genetic components of variance, their interactions with environments, and the ratio of additive and dominance variances from the combined analyses of variance across six environments for five traits measured in the DS7u and YuSSSu populations.

\begin{tabular}{|c|c|c|c|c|c|}
\hline \multirow[t]{2}{*}{ Trait* } & \multicolumn{4}{|c|}{ Genetic component of variance } & \multirow[b]{2}{*}{$\sigma_{\mathrm{D}}^{2} / \sigma^{2}$} \\
\hline & $\sigma_{\mathrm{A}}^{2}$ & $\sigma_{\mathrm{D}}^{2}$ & $\sigma_{\mathrm{AE}}^{2}$ & $\sigma_{\mathrm{DE}}^{2}$ & \\
\hline \multicolumn{6}{|c|}{ Oil content $(\%)$} \\
\hline $\mathrm{DS} 7 \mathrm{uC} 0$ & $0.22 * *$ & $0.09 * *$ & 0.03 & -0.08 & 0.41 \\
\hline DS7uC9 & $0.80 * *$ & $0.19^{* *}$ & 0.04 & -0.59 & 0.23 \\
\hline YuSSSuC0 & 0.13 & $0.08^{* *}$ & 0.01 & -0.14 & 0.61 \\
\hline YuSSSuC9 & 0.30 & 0.18 & -0.04 & -0.20 & 0.60 \\
\hline \multicolumn{6}{|c|}{ Grain yield $\left(\mathrm{Mg} \mathrm{ha}^{-1}\right)$} \\
\hline $\mathrm{DS} 7 \mathrm{uC} 0$ & $1.70^{* *}$ & $0.34 * *$ & $0.43 * *$ & $0.60 * *$ & 0.20 \\
\hline DS7uC9 & $0.93 * *$ & $0.28 * *$ & $0.40^{* *}$ & $0.38 * *$ & 0.30 \\
\hline YuSSSuC0 & $2.45^{* *}$ & $0.99 * *$ & $0.50 * *$ & $0.30 * *$ & 0.40 \\
\hline YuSSSuC9 & $1.81 * *$ & $2.09 * *$ & $0.52 * *$ & $0.94 * *$ & 1.15 \\
\hline \multicolumn{6}{|c|}{ Grain moisture (\%) } \\
\hline $\mathrm{DS} 7 \mathrm{uC} 0$ & $7.56^{* *}$ & $0.89 * *$ & 0.44 & $6.72 * *$ & 0.11 \\
\hline $\mathrm{DS} 7 \mathrm{uC} 9$ & $6.28 * *$ & 0.23 & $1.53 * *$ & $9.10 * *$ & 0.04 \\
\hline YuSSSuC0 & $2.70^{* *}$ & 0.04 & 0.27 & $4.66^{* *}$ & 0.01 \\
\hline YuSSSuC9 & $3.85^{* *}$ & 0.31 & 0.27 & $5.36 * *$ & 0.08 \\
\hline \multicolumn{6}{|c|}{ Cob proportion (\%) } \\
\hline $\mathrm{DS} 7 \mathrm{uC} 0$ & $4.89 * *$ & 0.47 & 0.33 & $22.22 * *$ & 0.15 \\
\hline $\mathrm{DS} 7 \mathrm{uC} 9$ & $11.57^{* *}$ & 0.61 & 1.29 & 4.96 & 2.12 \\
\hline YuSSSuC0 & $5.49^{* *}$ & $1.27 * *$ & 0.16 & 18.14 & 1.54 \\
\hline YuSSSuC9 & $3.01 * *$ & $2.48 * *$ & 0.38 & 9.42 & 0.52 \\
\hline \multicolumn{6}{|c|}{ Root and stalk lodging (\%) } \\
\hline $\mathrm{DS} 7 \mathrm{uC} 0$ & 2.87 & 0.43 & 4.04 & $10.82 * *$ & 0.10 \\
\hline $\mathrm{DS} 7 \mathrm{uC} 9$ & 8.69 & $18.38^{* *}$ & $44.84 * *$ & $18.94 * *$ & 0.05 \\
\hline YuSSSuC0 & 5.39 & 8.31 & $26.72 * *$ & $9.24 * *$ & 0.23 \\
\hline YuSSSuC9 & 9.70 & 5.01 & 13.28 & $14.76^{* *}$ & 0.82 \\
\hline
\end{tabular}

$\sigma_{\mathrm{A}}^{2}, \sigma_{\mathrm{D}}^{2}, \sigma_{\mathrm{AE}}^{2}$ and $\sigma_{\mathrm{DE}}^{2}$ are the additive, dominance, additive by environment interaction, and dominance by environment interaction components of variance, respectively.

*Grain yield, grain moisture, root and stalk lodging and cob proportion were measured in six environments, whereas oil content was measured in two environments.

**Estimate is greater than twice its standard error.

\section{Heritability estimates}

Relatively high and non-significant narrow-sense heritability for oil content (\%) was present in the initial cycles of both investigated populations $\left(h^{2} \mathrm{DS} 7 \mathrm{uC} 0=0.70\right.$ and $\left.h^{2} \mathrm{YuSSSuC0}=0.65\right)$. Mass selection resulted in the increase, i.e. the significant decrease of heratibility in the populations DS7u $\left(h^{2} \mathrm{DS} 7 \mathrm{uC} 9=0.85\right)$ and YuSSSu populations $\left(h^{2} \mathrm{YuSSSuC9}=0.13\right)$, respectively. Narrow-sense heritability for grain yield was highly significant and relatively high in the initial cycles of both populations $\left(h^{2} \mathrm{DS} 7 \mathrm{uC} 0=0.72\right.$ and $\left.h^{2} \mathrm{YuSSSuC0}=0.67\right)$. After nine cycles of recurrent selection loss of significance was determined in the population $\mathrm{DS} 7 \mathrm{u}$ population $\left(h^{2} \mathrm{DS} 7 \mathrm{uC} 9=\right.$ 0.65 ), while narrow-sense heratibility was significantly lowered and loss of significance occurred in the population
YuSSSu population $\left(h^{2}\right.$ YuSSSuC9 $\left.=0.43\right)$. Highly significant and high narrow-sense heratibility for grain moisture content was detected in all four populations. Completion of nine cycles of mass selection did not significantly affect heritability for this trait. Narrow-sense heritability for the percent of lodged and broken plants was low and insignificant in all populations. The decrease of narrow-sense heritability for the percent of lodged and broken plants occurred in the population DS7u population in the C9 cycle $\left(h^{2} \mathrm{DS} 7 \mathrm{uC0}=0.28: h^{2} \mathrm{DS} 7 \mathrm{uC} 9=0.19\right)$. On the other hand, corresponding estimates for the population YuSSSu population increased $\left(h^{2} \mathrm{YuSSSuC0}=0.19: h^{2} \mathrm{YuSSSuC9}=\right.$ 0.40), Table III.

The population DS7u population expressed highly significant and high narrow-sense heritability for the cob percent with the increase in the last selection cycle of selec- 
Table III - Estimates of heritability $\left(h^{2}\right)$ on a half-sib progeny mean basis from the combined analyses of variance across six environments from five measured traits in the DS7u and YuSSSu populations.

\begin{tabular}{|c|c|c|}
\hline Trait* & $h^{2}$ & Standard error \\
\hline \multicolumn{3}{|c|}{ Oil content $(\%)$} \\
\hline $\mathrm{DS} 7 \mathrm{uC} 0$ & 0.70 & 1.11 \\
\hline $\mathrm{DS} 7 \mathrm{uC} 9$ & 0.85 & 0.79 \\
\hline YuSSSuC0 & 0.65 & 1.45 \\
\hline YuSSSuC9 & 0.13 & 3.83 \\
\hline \multicolumn{3}{|c|}{ Grain yield $\left(\mathrm{mg} \mathrm{ha}^{-1}\right)$} \\
\hline $\mathrm{DS} 7 \mathrm{uC} 0$ & $0.72^{\bullet}$ & 0.33 \\
\hline DS7uC9 & 0.65 & 0.41 \\
\hline YuSSSuC0 & $0.67^{\bullet}$ & 0.25 \\
\hline YuSSSuC9 & 0.43 & 0.37 \\
\hline \multicolumn{3}{|c|}{ Grain moisture $\left(\mathrm{g} \mathrm{kg}^{-1}\right)$} \\
\hline $\mathrm{DS} 7 \mathrm{uC} 0$ & $0.78^{\vee}$ & 0.16 \\
\hline DS7uC9 & $0.75^{\circ}$ & 0.22 \\
\hline YuSSSuC0 & $0.75^{\bullet}$ & 0.24 \\
\hline YuSSSuC9 & $0.75^{\circ}$ & 0.21 \\
\hline \multicolumn{3}{|c|}{ Cob proportion (\%) } \\
\hline $\mathrm{DS} 7 \mathrm{uC} 0$ & $0.67^{\vee}$ & 0.24 \\
\hline DS7uC9 & $0.74^{\vee}$ & 0.19 \\
\hline YuSSSuC0 & $0.66^{\vee}$ & 0.22 \\
\hline YuSSSuC9 & $0.37^{\vee}$ & 0.38 \\
\hline \multicolumn{3}{|c|}{ Root and stalk lodging (\%) } \\
\hline $\mathrm{DS} 7 \mathrm{uC} 0$ & 0.28 & 1.03 \\
\hline DS7uC9 & 0.19 & 0.88 \\
\hline YuSSSuC0 & 0.19 & 0.96 \\
\hline YuSSSuC9 & 0.40 & 0.89 \\
\hline
\end{tabular}

"Grain yield, grain moisture, root and stalk lodging and cob proportion were measured in six environments, whereas oil content was measured in two environments.

"Estimate is greater than twice its standard error.

tion $\left(h^{2} \mathrm{DS} 7 \mathrm{C} 0=0.67: h^{2} \mathrm{DS7C} 9=0.74\right)$. Corresponding estimates for the population YuSSSu population decreased and amounted to $h^{2} \mathrm{YuSSSuC} 0=0.66: h^{2} \mathrm{YuSSSuC} 9=0.37$ (Table III).

\section{Phenotypic and additive genetic correlation}

No significant phenotypic or additive genetic correlations for oil content and grain yield were observed.

Weak, non-significant and negative phenotypic and additive genetic correlations between the grain oil content and the grain moisture were determined in the $\mathrm{DS} 7 \mathrm{uC} 0$ population. These correlations became positive and stronger in the same population in the C9. Correlations in YuSSSu were positive and weak in $\mathrm{C} 0$. Upon completion of mass selection great changes were observed in this population. The additive genetic correlation became significant, while the phenotypic correlation became highly significant.
Phenotypic and additive genetic correlations between the oil content and the percent of lodged and broken plants were non-significant in all populations.

Phenotypic and additive genetic correlations between the oil content and the cob percentage were non-significant in the $\mathrm{C} 0$ of both populations. For $\mathrm{C} 9$ only in YuSSSu populations, The correlations for $\mathrm{C} 9$ were statistically significant only in YuSSSu populations. Phenotypic and additive correlation between grain yield and moisture content was highly significant in $\mathrm{C} 0$ of both populations. After nine selection cycles of selection, correlation became non-significant only in YuSSSu, Table IV.

No significant phenotypic or additive genetic correlation was observed for grain yield and the percentage of lodged and broken plants in any population were was observed.

Highly significant and negative phenotypic and additive genetic correlation was detected between grain yield and the cob percent in $\mathrm{C} 0$ in both populations. In the course of nine cycles of mass selection, loss of significance occurred in additive genetic correlation in both populations and in phenotypic correlation in the YuSSSuC9 population (Table IV).

\section{Discussion}

\section{Effects of selection on population mean performance}

The highly significant increase in the oil content was confirmed after nine cycles of mass selection in both populations, $16.1 \%$ cycle $^{-1}$ and $12.8 \%$ cycle $^{-1}$ in the DS7u and YuSSSu populations, respectively. The nine cycles amounted to $144.6 \%$ and $115.6 \%$ for the DS7u and YuSSSu populations, respectively. As expected, results agree with those obtained by (Saratlic, 1994) who worked with the same populations and after seven selection cycles of selection achieved total increases of $120 \%$ and $97 \%$ for the DS7u and YuSSSu populations, respectively. Alexander (1962), Dudley (1977), Dudley et al. (1992), Misevic et al. (1989), Sprague and Brimhall (1950), and Spraque et al. (1952) obtained similar results through mass selection for high oil content.

Nine cycles of phenotypic recurrent selection for high oil content resulted in yield reductions in both populations. Yield was reduced from 8.95 to $7.81 \mathrm{mg} \mathrm{ha}^{-1}$, or $1.41 \%$ cy$\mathrm{cle}^{-1}$ in the DS7u population. The yield reduction in the population YuSSSu population was from 7.44 to $6.61 \mathrm{mg} \mathrm{ha}^{-1}$, or $1.24 \% \mathrm{cycle}^{-1}$. These results are consistent with those of Saratlic (1994) for the DS7u population, which indicated a yield reduction of $3.35 \%$ cycle $^{-1}$ after seven cycles of phenotypic recurrent selection for high oil content. Successful mass selection for high oil content leads to changes in correlated traits. Misevic et al. (1989) reported a total yield decrease of $1.72 \mathrm{mg} \mathrm{ha}^{-1}$ after $24 \mathrm{cy}-$ cles of mass selection in the Alexho population. The average per cycle decrease in grain yield was $0.07 \mathrm{mg} \mathrm{ha}^{-1}$. 
Table IV - Phenotypic (above diagonal) and additive genetic (below diagonal) correlations of half-sib progeny from the combined analyses of variance across six environments among five traits measured in the DS7u and YuSSSu populations.

\begin{tabular}{|c|c|c|c|c|c|c|}
\hline Trait* & Population & Oil content & Grain yield & Grain moisture & Cob proportion & Root and stalk lodging \\
\hline \multirow[t]{4}{*}{ Oil content $(\%)$} & $\mathrm{DS} 7 \mathrm{uC0}$ & & 0.11 & -0.01 & 0.08 & -0.15 \\
\hline & DS7uC9 & & -0.41 & 0.30 & -0.01 & 0.71 \\
\hline & YuSSSuC0 & & 0.07 & 0.03 & 0.08 & -0.08 \\
\hline & YuSSSuC9 & & -0.14 & $0.90^{*}$ & $0.81^{*}$ & -0.15 \\
\hline \multirow[t]{4}{*}{ Grain yield (mg ha ${ }^{-1}$ ) } & $\mathrm{DS} 7 \mathrm{uC} 0$ & 0.48 & & $0.20 * *$ & $-0.26^{* *}$ & 0.19 \\
\hline & DS7uC9 & -0.49 & & $0.19^{* *}$ & -0.24 & -0.07 \\
\hline & YuSSSuC0 & 0.08 & & $-0.23 * *$ & $-0.28 * *$ & -0.13 \\
\hline & YuSSSuC9 & -0.18 & & -0.10 & -0.14 & -0.12 \\
\hline \multirow[t]{4}{*}{ Grain moisture $\left(\mathrm{g} \mathrm{kg}^{-1}\right)$} & $\mathrm{DS} 7 \mathrm{uC} 0$ & -0.21 & $0.26^{* *}$ & & $0.29 * *$ & -0.09 \\
\hline & DS7uC9 & 0.45 & $0.22 * *$ & & $0.26^{* *}$ & -0.13 \\
\hline & YuSSSuC0 & 0.04 & $-0.27 * *$ & & $0.28 * *$ & $0.15^{*}$ \\
\hline & YuSSSuC9 & $0.97 * *$ & -0.15 & & $0.30 * *$ & -0.01 \\
\hline \multirow[t]{4}{*}{ Cob proportion (\%) } & $\mathrm{DS} 7 \mathrm{uC0}$ & 0.10 & $-0.34 * *$ & $0.35^{* *}$ & & -0.03 \\
\hline & DS7uC9 & -0.04 & $-0.27 * *$ & $0.34 * *$ & & -0.06 \\
\hline & YuSSSuC0 & 0.10 & $-0.35 * *$ & $0.36 * *$ & & 0.10 \\
\hline & YuSSSuC9 & $0.89 *$ & -0.19 & $0.37 * *$ & & 0.08 \\
\hline \multirow[t]{4}{*}{ Root and stalk lodging (\%) } & $\mathrm{DS} 7 \mathrm{uC0}$ & -0.17 & 0.30 & -0.13 & -0.08 & \\
\hline & DS7uC9 & 0.73 & -0.25 & -0.15 & -0.15 & \\
\hline & YuSSSuC0 & -0.09 & -0.27 & 0.18 & 0.13 & \\
\hline & YuSSSuC9 & -0.17 & -0.22 & -0.04 & 0.14 & \\
\hline
\end{tabular}

*** Significant at the 0.05 and 0.01 probability levels, respectively.

"Grain yield, grain moisture, root and stalk lodging and cob proportion were measured in six environments, whereas oil content was measured in two environments.

Dudley and Lambert (1992), Alexander (1962), Dudley (1974), Misovic and Dumanovic (1990), Miller and Brimhall (1954), Dudley et al. (1974), Miller et al. (1981) and others also obtained similar results. The decrease in grain yield in the selection program for high oil content is explained by negative correlation between these two traits. Furthermore, it is possible that there is not sufficient variability among selected genotypes (on the basis of oil content) for the continued selection progress and/or there are unfavourable linked genes for oil content and grain yield. The yield decrease of the YuSSSu population is not in agreement with results from Saratlic (1994). He obtained a yield increase of $0.003 \%$ cycle $^{-1}$ after seven cycles of mass selection for high oil content. This occurrence was explained by the fact that the population was derived from the BSSSC5 population and previously had five cycles of recurrent selection for improved grain yield. As a result the yield initial yield level in this population was high enough that the frequency of favourable alleles could be reduced in the course of selection for high oil content. Furthermore, the presence of pleiotropic effects of certain genes, which could be included in inheritance of oil content and grain yield, is possible. The YuSSSuC9 yield reduction in this paper could also be explained also by its origin. Namely, since $\mathrm{C} 0$ of this population had undergone five cycles of recurrent selection for grain yield, it is possible that a decrease in variability for yield has occurred, and due to high frequency of favourable alleles, the consequences appeared sooner than in C9. The opinion of the majority of authors is that mass selection for improvement of another trait without appropriate attention paid to grain yield will lead to the reduction in grain yield. For example, Martin and Russel (1984), working on stalk quality improvement in the BS1 population, found a grain yield decrease of $12.3 \%$ cycle $^{-1}$. Nyhus et al. (1989) reported a yield decrease of $5 \%$ cycle $^{-1}$ in BSAA and BSBB populations selected for resistance to the European corn borer, while a similar decrease was obtained by Klenke et al. (1986) in the BS9 population amounting to $5.7 \%$ cycle $^{-1}$.

\section{Effect of selection on genetic parameters}

Evaluated estimates of additive and dominance variances for grain oil content were highly significant for both $\mathrm{DS} 7 \mathrm{uC} 0$ and $\mathrm{C} 9$. After selection, the ratio between additive and dominance variance increased from 2.5 to 5 in favour of additive variance. The additive $\mathrm{x}$ environment and dominance $\mathrm{x}$ environment interaction variances were not significant, indicating that effects of environments on grain oil 
content were not significant. This agrees with the results from Genter et al. (1956), Welch (1969), Jellum et al. (1973), and Jellum and Morion (1966). Based on the oil content increase in the population per se, Saratlic (1994) indicated that additive gene effects were the most important types of gene action governing this trait. Misevic et al. (1989), Miller et al. (1981), El Rouby and Penny (1967), Misevic (1982), Moreno-Gonzales et al. (1975), and Hallauer and Miranda Filho (1988) also found greater importance for additive gene effects in control of oil content.

Non-significant estimates of additive variance and highly significant estimates of dominance variance for the oil content were found in the YuSSSuC0 population. Loss of significant dominance variance occurred in C9 of this population. The interaction between environments and additive and dominance variance was not significant for $\mathrm{C} 0$ or $\mathrm{C} 9$ of $\mathrm{YuSSSu}$. The ratio between additive and dominance variance in $\mathrm{YuSSSuC0}$ and $\mathrm{C} 9$ was 1.6:1 in favour of additive variance. Misevic et al. (1985) reported highly significant estimates of genetic drift and inbreeding depression in the YuSSSuC5 population that was probably a consequence of the selection process that was changed in $\mathrm{C} 4$, where instead of selecting the best ears for recombination, the best individual kernels were selected.

Estimates of additive and dominance variances for grain yield, as well as their interactions with environments, were highly significant in the DS7u population. The estimate of additive variance was five times greater than the estimate of dominance variance in $\mathrm{DS} 7 \mathrm{uC} 0$. Nine cycles of mass selection for high oil content did not result in significant changes in genetic estimates for grain yield. The numeric value for additive variance decreased and it was three times greater than the dominance variance in $\mathrm{DS} 7 \mathrm{uC}$. This can be used to explain the yield reduction over the course of selection for high oil content. Furthermore, this agrees with results obtained by Misevic (1982), who found that additive variance for grain yield was greater than dominance variance in the $U_{1}$ population (developed by crosses of the population Fords High Oil population with the population Indiana Synthetic A population). Also, the results of 99 studies on different maize populations (Hallauer and Miranda Filho, 1988) pointed out that the relation between additive and dominance variance for grain yield averaged 1.6:1 in favour of additive variance.

Estimates of additive and dominance variances for grain yield, as well as their interaction with environments, were highly significant in the YuSSSuC0 population. In contrast to the $\mathrm{DS} 7 \mathrm{uC} 0$ population, the ratio between additive and dominance variance in the YuSSSu population was 2.5:1. The numeric estimates of additive variance decreased over selection cycles of selection vs. dominance variance that increased, hence, the ratio between additive and dominance variance in C9 was 1:1.15 in favour of dominance. A survey of the literature indicated that maize improvement, i.e. an increase in the frequency of favourable alleles, resulted in different contributions and significance of genetic variance components for yield. Robinson (1963) pointed out that the additive component had greater significance in inheritance of grain yield and the majority of other traits in open-pollinated varieties and maize populations. As selection continued, the importance of additive variance decreased. Hence, the ratio between additive and dominance variance in grain yield inheritance was about equal (1:1) in the YuSSSuC0 population, which had previously undergone a high number of recurrent selection cycles. Oyervides-Garcia and Hallauer (1986), Helms et al. (1989), Keeratinijakal and Lamkey (1993) obtained similar results.

High narrow-sense heritability for oil content in $\mathrm{DS} 7 \mathrm{uC} 0$ increased even further following nine cycles of mass selection. This agrees with estimated components of genetic variance, since the proportion of additive variance had increased in C9. According to Hallauer and Miranda Filho (1988), oil content and number of tassel branches are the traits expressing high heritability. Narrow-sense heritability decreased from $h^{2}=0.65$ to $h^{2}=0.13$ in the YuSSSu population. Dudley and Lambert (1992) reported a similar estimate of heritability $\left(h^{2}=0.11\right)$ for grain oil content after 90 selection cycles of selection in the IHO population.

Narrow-sense heritability for grain yield was statistically significant and relatively high in the $\mathrm{C} 0$ of both populations. Loss of significance and decrease in heritability for grain yield occurred after nine cycles of mass selection cycles for high grain oil content. This specifically refers to the YuSSSu population in which heritability decreased from $h^{2}$ $=0.67$ to $h^{2}=0.43$, and it is in agreement with the estimated genetic variance components in which the proportion of additive variance decreased due to selection. Lamkey and Hallauer (1987) obtained similar results by looking at variances among progenies for 121 selection experiments from seven recurrent selection programmes (mass, ear-to-row, half-sib recurrent, S1-S2 recurrent, half-sib with genetically narrow-base tester, half-sib with broad-base tester, and reciprocal recurrent full-sib selection). Heritability for grain yield ranged from $53.3 \%$ (half-sib reciprocal recurrent selection with the use of an inbred tester) to $79.8 \%$ (S1 recurrent selection). Based on $50 \mathrm{~S} 1$ progenies, Walters et al. (1991) found decrease in heritability for grain yield from $83 \%$ for BSSSC0 to $68 \%$ for BS13(S)C3. Moreover, Stucker and Hallauer (1992), using a Design II study on the basis of 48 random inbred lines from BSSSC0 and $\mathrm{BS} 13(\mathrm{~S}) \mathrm{C} 1$, determined a decrease in heritability for grain yield from $75 \%$ in BSSSC0 to $67 \%$ in $\mathrm{BS} 13(\mathrm{~S}) \mathrm{C} 1$. Heritability depends to a great extent on the breeding population and environmental conditions, as well as the means of estimation, hence, one should be careful in interpretations and comparisons between heritability estimates from different experiments. 
The estimate of narrow-sense heritability for grain moisture was high $\left(h^{2}=0.75\right)$ and significant in both populations. This parameter was not significantly changed through selection. (Hallauer and Miranda Filho, 1988) analysed four experiments and concluded that the average estimate of heritability estimate for grain moisture was 0.62 .

Heritability for cob percentage was high and significant in the initial cycles of both populations. As a result of mass selection heritability did not change significantly. Cortez-Mendoza (1977), and Laible and Dirks (1968) obtained similar results.

A low, positive, additive correlation was observed between oil content and grain yield in the $\mathrm{C} 0$ of both populations. After nine cycles of mass selection for high oil content a moderate and negative, additive correlation was found in the DS7u populations and a low negative correlation was found in the YuSSSu population. Phenotypic correlations followed the trend for additive correlations. The majority of the studies on ratios between the oil content and grain yield show negative correlation. Misovic and Dumanovic (1990) explained this as arising because of the selection procedure applied in the majority of the breeding programs for high oil content. Namely, selection has been based on either increased oil content or increased oil content per unit weight without any, or almost any, attention paid to kernel weight per se. Such a selection procedure has resulted in increased oil content per unit weight or in the kernel, but at the same time in decreased kernel size. According to the same authors the relationship between grain yield and oil content in maize is still not clear. Many authors have reported correlations between grain yield and oil content (Miller and Brimhall, 1954; Alexander, 1962; Dudley et al., 1974; 1977; and Miller et al., 1981). Most suggested that oil content increases over $8 \%$ resulted in reduced grain yield. Saratlic (1994) detected a highly significant and negative correlation $(r=-0.99)$ between the grain oil content and grain yield in the S0 generation of the DS7u population. A great number of conclusions on the relation between the oil content and yield was made on the basis of the IHO-related material and could have been biased, because long-term selection might have reduced genetic variation for all other important agronomic traits except oil content. This is supported by finding positive correlations in the initial cycles of both populations observed in the present study. Alexander and Seif (1963), and Loffland and Quackenbush (1954) found no correlation between these two traits.

Saratlic (1994) found negative and high phenotypic correlations between grain yield and grain moisture, percentage of lodged and broken plants, and cob percent in populations the DS7u and YuSSSu populations, which is not in full agreement with results from the present study. This is explained by the fact that additive correlations are much more precise than phenotypic ones, as they typically have large standard errors. Based on results from nine ex- periments, Hallauer and Miranda Filho (1988) found an average genetic correlation between grain yield and the cob percentage of 0.10 , which agrees with results obtained in this study. Furthermore, the corresponding correlation between the mentioned traits obtained by the same authors was 0.13 in the BSSS population.

\section{Conclusion}

Changes of means, components of genetic variance, heritability, and additive and phenotypic correlations resulting from using mass selection for high oil content, were observed in the present study.

Nine cycles of mass selection resulted in a significant total increase in oil content of $16.1 \%$, and $12.8 \%$ cycle $^{-1}$ in the DS7u and YuSSSu populations, respectively. Grain yield was significantly reduced in both populations. The percentage of lodged and broken plants and the cob percentage significantly increased significantly in the DS7u population and significantly decreased in the YuSSSu population. Grain moisture content was significantly increased in the DS7u population, but remained the same in the YuSSSu population.

Estimates of additive and dominance variances for grain oil content were highly significant for $\mathrm{C} 0$ and $\mathrm{C} 9$ of DS7u. Only dominance variance showed significance in YuSSSuC0, but it was lost in the course of selection. Additive and dominance variances for grain yield were highly significant in both initial populations. Loss of significance through selection did not occur, but an increased proportion of dominance variance resulted from selection. Estimates of additive variance for the moisture content were highly significant in all populations, while dominance variance was significant only in $\mathrm{DS} 7 \mathrm{uC} 0$. The estimate of dominance variance for the percentage of lodged and broken plants was highly significant in the $\mathrm{DS} 7 \mathrm{uC} 9$ population. Highly significant estimates of additive variances were detected for the cob percent in both populations, while dominance variance was significant in the YuSSSu populations.

High, narrow-sense heritability was found for oil content, grain yield, moisture content and cob percentage in $\mathrm{C} 0$ of both populations. Mass selection resulted in increased heritability for oil content and cob percentage in the DS7u population and for the percentage of lodged and broken plants in the YuSSSu population. Narrow-sense heritability for oil content and cob percentage decreased in the YuSSSu population. Moisture content and the percentage of lodged and broken plant heritability decreased in the DS7u population and heritability for grain yield heritability decreased in both populations.

Weak additive correlation was detected between oil content and grain yield $\left(r_{\mathrm{a}}=0.11\right)$ in the $\mathrm{DS} 7 \mathrm{uC0}$ population. Mass selection affected this correlation and it became moderate and negative in $\mathrm{C} 9\left(r_{\mathrm{a}}=-0.41\right)$. For DS7uC9, the strongest additive correlation was found between oil content and the percentage of lodged and broken plants. A sim- 
ilar situation was observed for the additive correlation between oil content and grain yield in the YuSSSu population. For YuSSSuC9 The strongest additive correlations for YuSSSuC9 were detected between the oil and moisture content $\left(r_{\mathrm{a}}=0.90^{*}\right)$ and the oil content and cob percent $\left(r_{\mathrm{a}}=0.81^{*}\right)$.

As a general conclusion it can be stated that mass selection for increased oil content was very efficient in both populations. Sufficient additive variance and high estimates of heritability following selection were found only in the DS7u population, hence, this population would be used for future work on increased grain oil content. On the other hand, further work toward increased oil content in the YuSSSu population will be difficult.

\section{References}

Alexander DE (1962) Corn as an oil crop. 17th Hybrid Corn Industry Research Conference, 5-6 dec., IL, 85-91.

Alexander DE (1977) The status of high oil corn breeding. Proc. III. Corn Breeding School. Urbana, III, USA.

Alexander DE and Seif RD (1963) Relation of kernel oil content to some agronomic traits of maize. Crop Sci 3:354-357.

Comstock RE and Robinson HF (1948) The components of genetic variance in populations of biparental progenies and their use in estimating the average degree of dominance. Biometrics 4:254-266.

Cortez-Mendoza H (1977) Evaluation of ten generations of divergent mass selection for ear length in Iowa Long Ear Synthetic. PhD Thesis, Iowa State Univ., Ames.

Dudley JW, Lambert RJ and De La Roche IA (1977) Genetic analysis of crosses among corn strains divergently selected for percent oil and protein. Crop Sci 17:111-117.

Dudley JW (1973) Seventy generations of selection for oil and protein in corn kernel. Proc. $26^{\text {th }}$ Annual Corn and Sorghum Research Conference, pp 123-136.

Dudley JW (1974) Seventy generations of selection for oil and protein in the corn kernel. Proc. $28^{\text {th }}$ Annual Corn and Sorghum Research Conference, pp 123-136.

Dudley JW (1977) 76 Generations of selection for oil and protein percentage in maize. Proc. Int. Conf. on Quantitative Genetics. Ames, IA, ISU Press, pp 459-473.

Dudley JW and Lambert RJ (1992) Ninety generations of selection for oil and protein in maize. Maydica 37:81-87.

Dudley JW, Lambert RJ and Alexander DE (1974) Seventy generations of selection for oil and protein concentration in the maize kernel. In: Dudley JW (eds) Seventy generations of selection for oil and protein in maize. Crop Science of America, Medison, WI, USA, pp 181-212.

Dumanovic J (1995) Visokouljani kukuruz. Naucni bilten, Institut za kukuruz "Zemun Polje". Beograd-Zemun, Yugoslavia.

Edge M (1997) Seed management issues for "TopCross High Oil Corn". In: Cortes JE (eds) Proc. of the Nineteenth annual Seed Technology conference. Seed Science Centre, Iowa State University, USA, pp 49-55.

El Rouby MM and Penny LH (1967) Variation and covariation in a high oil population of corn (Zea mays L.) and their implications in selection. Crop Sci 7:216-219.

Falconer DS (1989) Introduction to quantitative genetics. 3rd edition. Longman, London and New York.
Genter CG, Eheart JF and Linkous WN (1956) Effect of location, hybrid, fertilizer and rate of planting on the oil and protein content of corn grain. Agron J 48:63-67.

Hallauer AR and Miranda JB (1988) Quantitative genetics in maize breeding. 2nd edition. Iowa State University Press, Ames, Iowa.

Helms TC, Hallauer AR and Smith OS (1989) Genetic drift and selection evaluated from recurrent selection program in maize. Crop Sci 29:602-607.

Jellum MD, Boswell FC and Young CT (1973) Nitrogen and boron effects on protein and oil corn grain. Agron J 65:330333.

Jellum MD and Marion JE (1966) Factor affecting oil content and oil composition of corn (Zea mays L.) grain. Crop Sci 6:259-266.

Keeratinijakal V and Lamkey KR (1993) Genetic effects associated with reciprocal recurrent selection in BSSS and BSCB1 maize populations. Crop Sci 33:78-82.

Klenke JR, Russel WA and Guthrie WD (1986) Recurrent selection for resistance to European corn borer in a corn synthetic and correlated effects on agronomic traits. Crop Sci. 26:864-868

Laible CA and Dirks VA (1968) Genetic variance and selective value of ear number in corn (Zea mays L.). Crop Sci 8:540543.

Lambert RJ, Alexander DE, Mollring EL and Wiggens B (1997) Selection for increased oil concentration in maize kernels and associated changes in several kernel traits. Maydica 42:39-43.

Lamkey KR and Hallauer AR (1987) Heritability estimated from recurrent selection experiments in maize. Maydica 32:6178.

Loffland HB and Quackenbush FW (1954) Distribution of fatty acids in corn oil. J Am Oil Chem Soc 31:412-417.

Martin MJ and Russel WA (1984) Correlated responses of yield and other agronomic traits to reccurent selection for stalk quality in maize synthetic. Crop Sci 24:746-750.

Miller PA and Brimhall B (1954) Factors influencing the oil and protein content of corn grains. Agron J 43:305-308.

Miller RL, Dudley JW and Alexander DE (1981) High intensity selection for percent oil in corn. Crop Sci 21:433-437.

Misevic D (1982) Geneticka varijabilnost i selekcioni indeks za prinos zrna, sadrzaj ulja i proteina i tezinu zrna u sintetickim populacijama kukuruza. Arhiv za poljoprivredne nauke 43:71-93.

Misevic D, Maric A, Alexander DE, Dumanovic J and Ratkovic S (1989) Population cross diallel among high oil populations of maize. Crop Sci 29:613-617.

Misevic D, Alexander DE, Dumanovic J and Ratkovic S (1985) Recurrent selection for percent oil in corn. Genetika 17:97106.

Misovic, M, and Dumanovic, J (1990) Breeding maize for increased oil content. International Advanced Course Maize Breeding, Production, Processing and Marketing in Mediterranean Countries, Maize 90, pp 99-117.

Mode CJ and Robinson HF (1959) Pleiotropism and the genetic variance and covariance. Biometrics 15:518-537.

Moreno-Gonzales J, Dudley JW and Lambert JR (1975) A design III study of linkage disequilibrium for percent oil in maize. Crop Sci 6:840-843. 
Nyhus KA, Russell WA and Guthrie WD (1989) Changes in agronomic traits associated with recurrent selection in two maize synthetics. Crop Sci 29:269-275.

Oyervides-Garcia M and Hallauer AR (1986) Selection induced differences among strains of Iowa Stiff Stalk Synthetic maize. Crop Sci 26:506-511.

Robinson FH (1963) Statistical Genetics and Plant Breeding. National Res Coun Publ 892:429-438.

Saratlic G (1994) Promene u frekvenciji pozeljnih alela za sadrzaj ulja kao posledica rekurentne selekcije kukuruza (Zea mays L.). Doktorska disertacija. Univerzitet u Novom Sadu, Poljoprivredni fakultet, Yugoslavia.

Satterthwaite FE (1946) An approximate distribution of estimates of variance components. Biometrics 2:110-114.

Smith LH (1908) Ten generations of corn breeding. Ill. Agr Exp Sta Bull 128:457-461.
Snedecor GW and Cochran WG (1989) Statistical Methods. 8th edition. Iowa State University Press, Ames.

Sprague GF and Brimhall B (1950) Relative effectiveness of two systems for selection for oil content of the corn kernel. Agron J 42:83-88.

Sprague GF, Miller PA and Brimhall B (1952) Additional studies of the relative effectiveness of two systems of selection for oil content of the corn kernel. Agron J 44:329-331.

Stucker DS and Hallauer AR (1992) Genetic variability as affected by selection in Iowa Stiff Stalk Synthetic maize. J Hered 83:410-418.

Walters SP, Russell WA and Lamkey KR (1991) Performance and genetic variance among $\mathrm{S}_{1}$ lines and testcrosses of Iowa Stiff Stalk Synthetic maize. Crop Sci 31:76-80.

Welch LF (1969) Effect of N, P and K on the percent and yield of oil in corn. Agron J 61:890-893.

Woodwort CM, Leng ER and Jugenhiemer RW (1952) Fifty generations of selection for oil and protein content in corn. Agron J 44:60-65. 